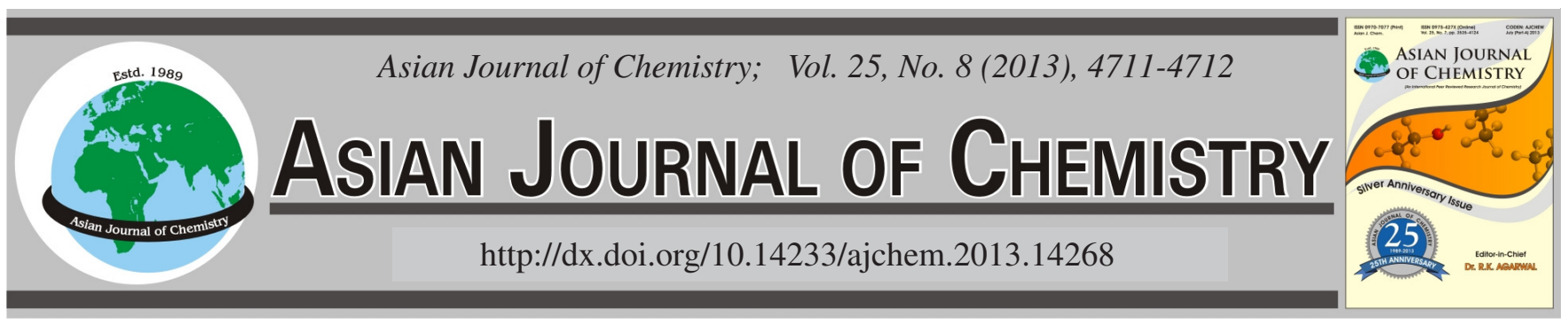

NOTE

\title{
Studies on Electronic Effects on the Singlet-Triplet Gap of Aryl- $\mathrm{C}_{4} \mathrm{H}_{3} \mathrm{Si}$
}

\author{
E. Vessally ${ }^{1, *}$, A. $\operatorname{KhANI}^{1}$, L. EdJlali ${ }^{2}$ and M. NiKoORAZM ${ }^{3}$
}

\begin{abstract}
${ }^{1}$ Department of Chemistry, Miyaneh Branch, Islamic Azad University, Miyaneh, Iran
${ }^{2}$ Department of Chemistry, Tabriz Branch, Islamic Azad University, Tabriz, Iran

${ }^{3}$ Department of Chemistry, University of Ilam, Ilam, Iran

*Corresponding author: E-mail: vessally@yahoo.com
\end{abstract}

(Received: 6 July 2012;

Accepted: 26 February 2013)

AJC-13053 The thermal energies (E), enthalpies $(\mathrm{H})$ and Gibbs free energies $(\mathrm{G})$ and their gap energies between singlet (s) and triplet (t) states
including $\Delta \mathrm{E}_{\mathrm{s}-\mathrm{t}}, \Delta \mathrm{H}_{\mathrm{s}-\mathrm{t}}$ and $\Delta \mathrm{G}_{\mathrm{s}-\mathrm{t}}$ of $\mathrm{Ar}-\mathrm{C}_{4} \mathrm{H}_{3} \mathrm{Si}\left(\mathrm{G}=-\mathrm{NH}_{2},-\mathrm{OH},-\mathrm{CH}_{3},-\mathrm{F},-\mathrm{Cl},-\mathrm{Br},-\mathrm{H},-\mathrm{CF}_{3}\right.$ and $\left.-\mathrm{NO}_{2}\right)$ were studied at $\mathrm{B} 3 \mathrm{LYP} / 6-311++\mathrm{G}^{* *}$
level of theory.

Key Words: Silylene, Singlet-triplet gap, Electronic effects.

Divalent carbenes and their analogues are strongly reactive ${ }^{1}$. The cyclic completely conjugated species are important in the chemistry of divalent carbene intermediates ${ }^{2}$. These divalent structures were formerly described in terms of the Huckel $4 n+2$ rule $^{3}$. However, non-planar isomers are found energy minima for most of these singlet cyclic conjugated carbenes through semi-empirical studies ${ }^{4}$. The isolation of the stable five membered cyclic conjugated carbene is firstly reported by Arduengo et al. ${ }^{5}$ and then $\mathrm{Su}$ and $\mathrm{Chu}^{5}$. Since most of divalent carbenes and their analogues are unstable, theoretical calculation was required for analysis of their properties. In continuation of our studies ${ }^{2,6}$, in this manuscript, the singlettriplet gap energies were studied on $\mathrm{Ar}-\mathrm{C}_{4} \mathrm{H}_{3} \mathrm{Si}\left(\mathrm{G}=-\mathrm{NH}_{2}\right.$, $-\mathrm{OH},-\mathrm{CH}_{3},-\mathrm{F},-\mathrm{Cl},-\mathrm{Br},-\mathrm{H},-\mathrm{CF}_{3}$ and $-\mathrm{NO}_{2}$ ).

Full geometry optimizations of $\mathrm{Ar}-\mathrm{C}_{4} \mathrm{H}_{3} \mathrm{Si}$ were carried out by density functional theory, DFT, method using 6-311++ $\mathrm{G}^{* *}$ basis set of the GAUSSIAN 98 program $^{7-9}$ (Scheme-I). To find a global minimum on a specific surface, all possible conformations of the given species were examined through scanning the specific dihedral angles at B3LYP/6-311++G** level. All calculations were carried out for gas phase at $298 \mathrm{~K}$ temperature and $1 \mathrm{~atm}$ pressure.

The thermal energies (E), enthalpies (H), Gibbs free energies $(\mathrm{G})$ and their gap energies between singlet (s) and triplet (t) states including $\Delta \mathrm{E}_{\mathrm{s}-\mathrm{t}}, \Delta \mathrm{H}_{\mathrm{s}-\mathrm{t}}$ and $\Delta \mathrm{G}_{\mathrm{s}-\mathrm{t}}$ of $\mathrm{Ar}-\mathrm{C}_{4} \mathrm{H}_{3} \mathrm{Si}$ $\left(\mathrm{G}=-\mathrm{NH}_{2},-\mathrm{OH},-\mathrm{CH}_{3},-\mathrm{F},-\mathrm{Cl},-\mathrm{Br},-\mathrm{H},-\mathrm{CF}_{3}\right.$ and $\left.-\mathrm{NO}_{2}\right)$ were calculated at B3LYP/6-311++G** level of theory (Scheme-I and Table-1). The gap free energies, $\Delta \mathrm{G}_{\mathrm{s}-\mathrm{t}}$, for various substituents were changed in the followed order: $-\mathrm{Br}>-\mathrm{CF}_{3}>-\mathrm{NO}_{2}$ $>-\mathrm{H}>-\mathrm{Cl}>-\mathrm{CH}_{3}>-\mathrm{F}>-\mathrm{NH}_{2}>-\mathrm{OH}$.

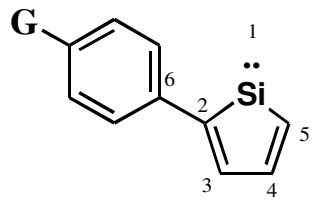

\section{$\mathrm{G}=-\mathrm{NH}_{2},-\mathrm{OH},-\mathrm{CH}_{3},-\mathrm{F},-\mathrm{Cl},-\mathrm{Br},-\mathrm{H},-\mathrm{CF}_{3}$ and $-\mathrm{NO}_{2}$}

Scheme-I: Electron donating substituents $\left(\mathrm{G}=-\mathrm{NH}_{2},-\mathrm{OH},-\mathrm{CH}_{3},-\mathrm{F},-\mathrm{Cl}\right.$ and $-\mathrm{Br})$ and electron withdrawing substituents $\left(\mathrm{G}=-\mathrm{CF}_{3}\right.$ and $\left.-\mathrm{NO}_{2}\right)$ of $\mathrm{Ar}-\mathrm{C}_{4} \mathrm{H}_{3} \mathrm{Si}$

Calculated $\Delta \mathrm{G}_{\mathrm{s}-\mathrm{t}}$ shows that the electron donating substituents $\left(\mathrm{G}=-\mathrm{NH}_{2},-\mathrm{OH},-\mathrm{CH}_{3},-\mathrm{F},-\mathrm{Cl}\right.$ and $\left.-\mathrm{Br}\right)$ at phenyl group cause to increase $\Delta \mathrm{G}_{\mathrm{s}-\mathrm{t}}$ while the electron withdrawing substituents $\left(\mathrm{G}=-\mathrm{CF}_{3}\right.$ and $\left.-\mathrm{NO}_{2}\right)$ lead to decrease the $\Delta \mathrm{G}_{\mathrm{s}-\mathrm{t}}$ of Ar- $\mathrm{C}_{4} \mathrm{H}_{3} \mathrm{Si}$. Therefore, changing substituents at phenyl groups from an electron donating toward an electron withdrawing groups lead to increase of the $\Delta \mathrm{G}_{\mathrm{s}-\mathrm{t}}$. Relative energy analysis reveals that the substitution of the electron donating groups at phenyl group leads to the instability of the singlet state while the substitution of the electron withdrawing groups leads to the stability of the singlet state.

The electron withdrawing groups at phenyl groups enforce a higher percentage of $s$-character on nonbonding electrons at the silylenic center of $\mathrm{Ar}-\mathrm{C}_{4} \mathrm{H}_{3} \mathrm{Si}$. The higher $s$-character of nonbonding electrons leads to the stability of the singlet state as well as increase the singlet-triplet gap $\Delta \mathrm{G}_{\mathrm{s-t}}$. Furthermore, the electron withdrawing groups at phenyl groups cause a high polarity of: $\mathrm{Si}-\mathrm{C}$ in the direction: $\mathrm{Si}^{+}-\mathrm{C}^{-}$. Strongly polarized bond leads to more stability of the singlet state as well as increase the singlet-triplet gap $\Delta \mathrm{G}_{\mathrm{s}-\mathrm{t}}$. 


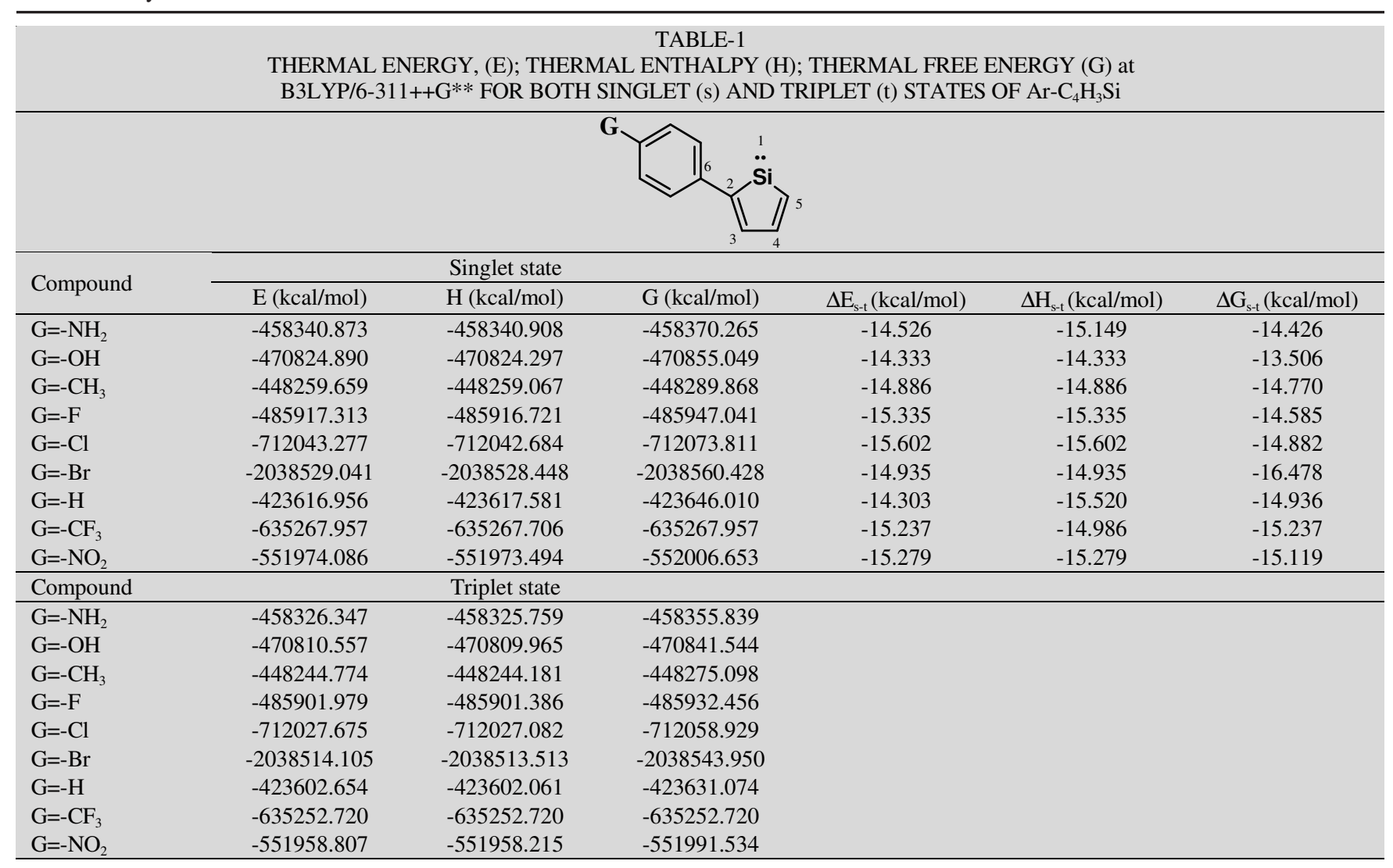

The B3LYP/6-311++G** calculations indicated that the bond length $\mathrm{Si}_{1}-\mathrm{C}_{2}$ for the singlet states of $\mathrm{Ar}-\mathrm{C}_{4} \mathrm{H}_{3} \mathrm{Si}$ increase with substitution of the electron donating groups while decrease with substitution of electron withdrawing groups at phenyl group. The bond length of $\mathrm{Si}_{1}-\mathrm{C}_{2}$ is higher respect to $\mathrm{Si}_{1}-\mathrm{C}_{5}$ for both singlet and triplet states of $\mathrm{Ar}-\mathrm{C}_{4} \mathrm{H}_{3} \mathrm{Si}$. Therefore, it could be concluded that a carbenic character was constructed instead of an allenic character for both singlet and triplet states of $\mathrm{Ar}-\mathrm{C}_{4} \mathrm{H}_{3} \mathrm{Si}$. Carbenic character was not significantly affected by substitution of electron withdrawing or electron donating groups at phenyl group.

The bond angle $\angle \mathrm{A}_{2,1,5}$ for singlet states of $\mathrm{Ar}-\mathrm{C}_{4} \mathrm{H}_{3} \mathrm{Si}$ is more than for triplet state (Table-1). This is inconsistent for acyclic carbenes. The DFT calculations indicated that bond angle $\angle \mathrm{A}_{2,1,5}$ for both singlet and triplet states of $\mathrm{Ar}-\mathrm{C}_{4} \mathrm{H}_{3} \mathrm{Si}$ was increased through replacement of electron withdrawing groups at phenyl group.

DFT calculations specified that the dihedral angle $\angle \mathrm{D}_{2,1,5,4}$ for both singlet and triplet states of $\mathrm{Ar}-\mathrm{C}_{4} \mathrm{H}_{3} \mathrm{Si}$ were not changed with substitution of the electron donating groups while increase with substitution of electron withdrawing groups at phenyl group.

\section{Conclusion}

B3LYP/6-311++G** calculations indicated that a carbenic character was constructed instead of an allenic character for both singlet and triplet states of $\mathrm{Ar}-\mathrm{C}_{4} \mathrm{H}_{3} \mathrm{Si}$. Calculated $\Delta \mathrm{G}_{\mathrm{s}-\mathrm{t}}$ shows that the electron donating substituents at phenyl group cause to increase of the $\Delta \mathrm{G}_{\mathrm{s}-\mathrm{t}}$ while the electron withdrawing substituents lead to decrease the $\Delta \mathrm{G}_{\mathrm{s}-\mathrm{t}}$ of $\mathrm{Ar}-\mathrm{C}_{4} \mathrm{H}_{3} \mathrm{Si}$.

\section{ACKNOWLEDGEMENTS}

The authors express our special thanks to Miyaneh Branch, Islamic Azad University for their financial support.

\section{REFERENCES}

1. P.P. Gaspar and R. West In: Z. Rappoport and Y. Apeloig, Editors, Chemistry of organic silicon compounds Wiley, Chichester, vol. 2 (1997).

2. M.Z. Kassaee, S. Arshadi, M. Acedy and E. Vessally, J. Organometal. Chem., 690, 3427 (2005).

3. (a) R. Gleiter and R. Hoffmann, J. Am. Chem. Soc., 90, 5457 (1968); (b) H. Kollmar, J. Am. Chem. Soc., 100, 2660 (1978); (c) L. Radom, H.F. Schaefer III and M.A. Vincent, Nouv. J. Chim., 4, 411 (1980).

4. M.Z. Kassaee, M.R. Nimlos, K.E. Downie and E.E. Waali, Tetrahedron, 41, 1579 (1985).

5. (a) M. Su and S. Chu, Inorg. Chem., 38, 4819 (1999); (b) A.J. Arduengo, R.L. Harlow and M. Kline, J. Am. Chem. Soc., 113, 361 (1991).

6. (a) E. Vessally, A. Rezaei, N. Chaliyavi and M. Nikoorazm, Russian J. Phys. Chem., 81, 1821 (2007); (b) E. Vessally, A. Rezaei, N. Chaliyavi and M. Nikoorazm, J. Chinese Chem. Soc., 54, 1583 (2007); (c) E. Vessally, A. Rezaei, N. Chaliyavi and M. Nikoorazm, Asian J. Chem., 19, 5000 (2007); d) A. Rezaie Rod and E. Vessally, Asian J. Chem., 19, 1709 (2007).

7. C. Lee, W. Yang and R.G. Parr, Phys. Rev. B, 37, 785 (1988).

8. A.D. Becke, J. Chem. Phys., 98, 5648 (1993).

9. M.J. Frisch, G.W. Trucks, H.B. Schlegel, G.E. Scuseria, M.A. Robb, J.R. Cheeseman, V.G. Znkrzewski, G.A. Montgomery Jr., R.E. Startmann, J.C. Baurant, S. Dapprich, J.M. Millam, A.D. Daniels, K.N. Kudin, M.C. Strain, O. Farkas, J. Tomasi, V. Barone, M. Cossi, R. Cammi, B. Mennucci, C. Pamelli, G. Adamo, S. Clifford, J. Octherski, G.A. Petersson, P.Y. Ayala, Q. Cui, K. Morokoma, D.K. Malick, A.D. Rubuck, K. Raghavachari, J.B. Foresman, J. Cioslawski, J.V. Ortiz, B.B. Stlefanov, G. Liu, A. Liashenko, P. Piskorz, I. Komaromi, R. Comperts, R.L. Martin, P.J. Fox, T. Keith, M.A. Al-laham, C.Y. Peng, A.N. Akkara, C.G. Gonzales, M.C. Combe, P.M.W. Gill, B. Johnson, W. Chem, M.W. Wong, J.L. Andres, C. Gonzales, M. Head-Gordon, E.S. Replogle and J.A. Pople, Gaussian 98, Revision A. 6, Gaussian Inc., Pittsburgh PA (1998). 